\title{
PERBANDINGAN KINERJA PEMERINTAH DAERAH DI INDONESIA
}

\author{
Netty Nurhayati1 ${ }^{1}$, Fahmi Rizani ${ }^{2}$, Kadir $^{3}$ \\ Universitas Lambung Mangkurat, Kota Banjarmasin, Kalimantan Selatan
}

\section{A R T I C L E I N F O}

\author{
Article history: \\ Received 9 April 2019 \\ Revised 29 Mei 2019 \\ Accepted 17 Juni 2019
}

\section{Key words:}

Financial performance, Performance of local government administration, BPK Opinion, Financial Ratio, EKPPD

\begin{abstract}
A B S T R A C T
This study aims to compare the performance of district / city governments in Indonesia that obtain WTP and Non-WTP opinion from BPK RI for 2014-2016 period. The financial performance variables are measured by financial ratios (decentralization degree ratio, independence ratio, effectiveness ratio, growth ratio) and performance of local government administration are measured by performance evaluation score of local government administration (EKPPD score). Sampling method using purposive sampling with judgment sampling technique. The sample in this study 216 districts $/$ cities, consisting of 108 districts / cities that obtain WTP opinion and 108 districts / cities that obtain Non-WTP opinion. Hypothesis testing using nonparametric test 'Mann-Whitney U Test'. The results of this study, state that the financial performance of local government and performance of local government administration on district 1 city governments in Indonesia that obtain WTP opinion is significantly different and better than district / city governments in Indonesia that obtained Non-WTP opinion. This difference shows that district / city government that obtain WTP opinion has proven to be better in terms of financial management and local government administration compared to those who obtain Non WTP opinions.
\end{abstract}

\begin{abstract}
A B S T R A K
Penelitian ini bertujuan untuk membandingkan kinerja pemerintah kabupaten/kota di Indonesia yang memperoleh opini WTP dan Non WTP dari BPK RI periode tahun 2014-2016. Variabel kinerja keuangan daerah diukur dengan rasio keuangan ( rasio derajat desentralisasi, rasio kemandirian, rasio efektivitas, rasio pertumbuhan) dan kinerja penyelenggaraan pemerintahan daerah diukur dengan skor Evaluasi Kinerja Penyelenggaraan Pemerintahan Daerah (EKPPD). Metode pengambilan sampel yang digunakan adalah purposive sampling dengan teknik judgment sampling. Sampel dalam penelitian ini 216 kabupaten/kota, terdiri dari 108 kabupaten/kota yang beropini WTP dan 108 kabupaten/ kota yang beropini Non WTP. Pengujian hipotesis menggunakan uji nonparametrik 'Mann-Whitney U Test'. Hasil dari penelitian ini, menyatakan bahwa baik kinerja keuangan daerah maupun kinerja penyelenggaraan pemerintahan daerah pada pemerintah kabupaten/kota seIndonesia yang memperoleh opini WTP berbeda secara signifikan dan lebih baik daripada pemerintah kabupaten/kota se-Indonesia yang memperoleh opini Non WTP. Perbedaan ini mem-perlihatkan bahwa pemerintah daerah yang memiliki opini WTP terbukti lebih baik dalam hal pengelolaan keuangan dan penyelenggaraan pemerintahan daerah nya di-bandingkan dengan yang memperoleh opini Non WTP.
\end{abstract}

\section{PENDAHULUAN}

Pelaksanaan APBD yang dituangkan dalam LKPD merupakan bentuk dari pertanggungjawaban pemerintah daerah sebagai agent atas pendelegasian wewenang yang diberikan oleh masyarakat/DPRD sebagai principal. Pemerintah daerah diharapkan memberikan pelayanan kepada masyarakat dengan sebaik-baiknya melalui penggunaan APBD. Untuk menghindari adanya asimetris informasi yang dapat menimbulkan masalah keagenan, maka LKPD wajib diserahkan kepada BPK RI untuk di audit sebagaimana diatur dalam Peraturan Pemerintah No.58 Tahun 2005 tentang Pengelolaan Keuangan Daerah pada pasal 100 ayat (6) dan pasal 102 ayat (2). Audit atas LKPD menghasilkan Laporan Hasil Pemeriksaan

\footnotetext{
*Corresponding author,email address:nurhayati.netty@gmail.com¹,fahmirizani@yahoo.com²,akdir4321@gmail.com³
} 
(LHP) yang memuat opini audit. Opini audit menurut Undang-Undang Nomor 15 Tahun 2004 adalah pernyataan profesional dari auditor berupa kesimpulan terkait tingkat kewajaran informasi yang disajikan dalam laporan keuangan.

Tahun 2017 BPK RI telah melakukan audit atas LKPD tahun 2016 untuk 508 pemerintah kabupaten/kota seluruh Indonesia. Berdasarkan hasil audit, tercatat bahwa 347 pemerintah kabupaten/kota memperoleh opini WTP dan jika dibandingkan dengan tahun sebelumnya terjadi peningkatan perolehan opini WTP oleh pemerintah kabupaten/kota atas LKPD tahun 2016. Perkembangan opini LKPD dari pemerintah kabupaten/kota secara nasional untuk audit LKPD tahun 2012 sampai dengan tahun 2016 adalah sebagai berikut:

Tabel 1.

Perkembangan Opini LKPD Kabupaten/Kota Tahun 2012-2016

\begin{tabular}{|c|c|c|c|c|c|c|c|c|}
\hline \multirow{3}{*}{$\begin{array}{l}\text { LKPD } \\
\text { (Tahun) }\end{array}$} & \multicolumn{8}{|c|}{ OPINI AUDIT } \\
\hline & \multicolumn{4}{|c|}{ KABUPATEN } & \multicolumn{4}{|c|}{ KOTA } \\
\hline & WTP & WDP & TMP & TW & WTP & WDP & TMP & TW \\
\hline 2012 & $18 \%$ & $63 \%$ & $17 \%$ & $2 \%$ & $33 \%$ & $59 \%$ & $8 \%$ & $0 \%$ \\
\hline 2013 & $26 \%$ & $61 \%$ & $10 \%$ & $3 \%$ & $38 \%$ & $59 \%$ & $3 \%$ & $0 \%$ \\
\hline 2014 & $41 \%$ & $50 \%$ & $8 \%$ & $1 \%$ & $60 \%$ & $40 \%$ & $0 \%$ & $0 \%$ \\
\hline 2015 & $54 \%$ & $38 \%$ & $7 \%$ & $1 \%$ & $65 \%$ & $33 \%$ & $2 \%$ & $0 \%$ \\
\hline 2016 & $66 \%$ & $29 \%$ & $5 \%$ & $0 \%$ & $77 \%$ & $22 \%$ & $1 \%$ & $0 \%$ \\
\hline
\end{tabular}

Sumber : IHPS II, 2017

Tabel perkembangan opini LKPD kabupaten/kota tahun 2012 sampai dengan tahun 2016 menunjukkan adanya peningkatan yang signifikan dari opini LKPD untuk pemerintah kabupaten/kota yang memperoleh opini WTP. Opini WTP pemerintah kabupaten tahun 2016 meningkat sekitar 48\% dari tahun 2012. Sementara opini WTP untuk pemerintah kota tahun 2016 meningkat sebesar $44 \%$ dari tahun 2012.

Keberhasilan pelaporan pengelolaan keuangan daerah yang diwujudkan dengan perolehan opini WTP idealnya juga mencerminkan keberhasilan dalam pengelolaan keuangan daerah tersebut. Keberhasilan dalam pelaporan dan pengelolaan keuangan tentunya juga akan berdampak positif terhadap penyelenggaraan pemerintahan daerah. Pemerintah yang memiliki pengelolaan keuangan yang baik serta didukung dengan kehandalan dalam pelaporannya akan diikuti dengan keberhasilan dalam kinerja penyelenggaraan pemerintahan daerah. Artinya baik kinerja keuangan ataupun penyelenggaraan pemerintahan daerah yang memperoleh opini WTP harusnya berbeda dengan yang memperoleh opini Non WTP.

Hal ini sejalan dengan hasil penelitian Masdiantini \& Erawati (2016) yang mengungkapkan bahwa opini audit BPK berpengaruh positif signifikan pada kinerja keuangan pemerintah kabupaten/kota se-Bali. Artinya semakin baik opini audit yang diberikan oleh BPK atas LKPD, maka seharusnya semakin baik pula kinerja pemerintah daerah dalam pengelolaan keuangannya. Hal ini menunjukkan bahwa idealnya pemerintah daerah yang memperoleh opini WTP juga memiliki kinerja keuangan yang lebih baik dibandingkan dengan daerah yang memperoleh opini Non WTP. Begitu juga dengan penelitian Sutopo, Wulandari, Adiati, \& Saputra (2017) yang menyatakan bahwa opini auditor memiliki hubungan positif dengan kinerja penyelenggaraan pemerintahan daerah, dengan demikian pemerintah daerah yang memiliki opini audit yang lebih baik cenderung memiliki kinerja yang lebih tinggi.

Pemerintah kabupaten/kota yang memperoleh opini WTP kenyataannya tidak selalu diikuti dengan keberhasilan dalam kinerja pemerintah daerah. Opini WTP yang diperoleh pemerintah daerah atas LKPD belum bisa menjadi acuan atas keberhasilan kinerja keuangan pemerintah daerah, dikarenakan opini WTP hanya sebatas pada keberhasilan administratif saja (Evana dalam Khairudin, 2013). Terbukti beberapa pemerintah kabupaten/kota seperti Kota Madiun, Kota Cimahi, Kab.Banyuasin, Kab.Sumedang, Kab.Buton, Kab.Tanggamus, Kab.Nganjuk dan Kab.Lombok Barat yang memperoleh opini WTP atas LKPD tahun 2015 namun kepala daerahnya terjerat kasus korupsi (Menteri Dalam Negeri Republik Indonesia, 2016).

Opini WTP juga tidak menjamin suatu daerah memiliki tingkat kesejahteraan yang tinggi. Sementara sesuai dengan UUD 1945 pasal 23 ayat (1) berbunyi: "anggaran pendapatan dan belanja negara sebagai wujud dari pengelolaan keuangan negara ditetapkan setiap tahun dengan undang-undang dan 
dilaksanakan secara terbuka dan bertanggung jawab untuk sebesar-besarnya kemakmuran rakyat." Namun, kenyataannya dari segi kesejahteraan masyarakat di daerah yang memperoleh opini WTP tidak berbeda atau bahkan dibawah daerah yang memperoleh opini Non WTP. Diantaranya Kab.Asmat, Kab.Fak-fak, Kab.Jayawijaya, Kab.Lombok Utara, Kab.Maybrat, Kab.Sorong, Kab.Sumba Timur dimana presentasi penduduk miskinnya masih diatas 25\% (Badan Pusat Statistik, 2018).

Keberhasilan kinerja penyelenggaraan pemerintahan daerah juga belum tergambar dari beberapa kabupaten/kota yang memperoleh opini WTP diantaranya adalah Kab.Maybrat, Kab.Muna, Kab.Nabire, Kab.Simeulue yang hanya memperoleh status S. Bahkan ada beberapa kabupaten/kota yang memperoleh opini WTP namun masuk dalam kategori 10 besar penyelenggaraan pemerintahan kabupaten/kota yang berprestasi paling rendah secara nasional yaitu Kab.Maybrat, Kab.Muna, Kota Palangkaraya, Kota Sabang dan Kota Subulussalam (Menteri Dalam Negeri Republik Indonesia, 2018).

Terdapat beberapa penelitian sejenis yang dilakukan oleh peneliti terdahulu. Namun terdapat adanya research gap yang masih memperlihatkan perbedaan pada hasil temuannya. Khairudin (2013) menemukan bahwa pemerintah kabupaten/kota se-Indonesia yang memperoleh opini WTP memiliki kinerja keuangan yang lebih baik dan berbeda secara signifikan dibandingkan dengan yang memperoleh opini Non WTP. Begitu juga dengan penelitian Taufik, Darwanis \& Arfan (2014) serta Tarmizi, Khairudin \& Jayadi (2014) yang memperlihatkan bahwa kinerja keuangan pemerintah daerah yang memperoleh opini WTP lebih baik dibandingkan dengan yang memperoleh opini Non WTP. Namun tidak demikian dengan Dary \& Yahya (2016) yang menemukan bahwa kinerja keuangan PAD periode opini Non WTP tidak berbeda dengan kinerja keuangan PAD periode opini WTP. Yasmin (2016) menemukan bahwa kinerja penyelenggaraan pemerintahan daerah pada pemerintah kabupaten/kota yang memperoleh opini WTP berbeda secara signifikan dengan pemerintah kabupaten/kota yang memperoleh opini Non WTP. Berbeda dengan hasil penelitian Heriningsih (2015) yang menemukan bahwa tidak terdapat perbedaan antara kinerja penyelenggaraan pemerintahan daerah pada kabupaten/kota yang memperoleh opini WTP dengan yang memperoleh opini selain WTP.

Uraian latar belakang dan fenomena gap di atas membuat peneliti tertarik untuk menganalisis apakah terdapat perbedaan kinerja pada pemerintah daerah yang memperoleh opini WTP dan opini Non WTP. Keinginan untuk melakukan uji beda atas kinerja tersebut juga diperkuat dengan adanya research gap pada penelitian terdahulu. Penelitian ini merupakan pengembangan dari penelitian Khairudin (2013) dan Yasmin (2016). Variabel kinerja keuangan pemerintah daerah yang digunakan dalam penelitian ini merujuk pada penelitian Khairudin (2013), sementara penambahan variabel kinerja penyelenggaraan pemerintahan daerah yang diukur dengan skor EKPPD dalam penelitian ini merujuk pada penelitian Yasmin (2016). Alasan peneliti menambahkan variabel kinerja penyelenggaraan pemerintahan daerah dikarenakan peneliti ingin mengetahui perbedaan kinerja pemerintah daerah antara yang memperoleh opini WTP dengan opini Non WTP tidak hanya dari segi keuangannya saja, tetapi juga dari segi penyelenggaraan pemerintahan daerahnya. Hal ini dikarenakan keberhasilan dalam pengelolaan keuangan suatu daerah harusnya juga akan berpengaruh terhadap penyelenggaraan pemerintahan daerahnya.

\section{TELAAH LITERATUR DAN PENGEMBANGAN HIPOTESIS \\ Teori Keagenan (Agency Theory)}

Jensen \& Meckling (1976) menjelaskan bahwa hubungan keagenan merupakan contract atau kesepakatan yang melibatkan principal dan agent, dimana terjadi pendelegasian wewenang dari agent kepada principal. Teori keagenan dalam organisasi sektor publik memperlihatkan hubungan keagenan antara pemerintah daerah sebagai agent dan masyarakat atau Dewan Perwalikan Rakyat Daerah (DPRD) sebagai principal (Halim \& Abdullah, 2006). Dalam organisasi sektor publik, masalah keagenan dapat terjadi dikarenakan masyarakat/ DPRD meragukan apakah laporan pertanggungjawaban atas pelaksanaan APBD yang dibuat oleh pemerintah daerah menyajikan informasi yang akuntabel dan transparan. Dalam rangka menghindari masalah keagenan ini, maka dibuatlah peraturan yang mengharuskan untuk dilakukan pemeriksaan atas LKPD tersebut oleh auditor eksternal (BPK RI) sehingga muncul agency cost.

\section{Teori Stakeholder (Stakeholder Theory)}

Gray (2001) mendefinisikan stakeholder sebagai pihak-pihak yang memiliki kepentingan terhadap perusahaan atau organisasi, yang dapat mempengaruhi dan dapat dipengaruhi oleh aktivitas perusahaan atau organisasi, stakeholder tersebut antara lain masyarakat, pemerintah, karyawan, supplier, pasar modal 
dan lain-lain. Mahmudi (2016, pp. 7-8) menyatakan bahwa stakeholder pemerintah daerah adalah masyarakat, investor, pegawai pemerintah daerah, penyedia barang dan jasa, DPRD, badan pengawas dan advokasi, rating agencies, pemerintah pusat, pemerintah daerah lain, lembaga-lembaga internasional dan manajemen. Penerapan teori ini pada organisasi sektor publik khususnya pemerintah, dalam hal menegakkan akuntabilitas dan transparansi, dimana pemerintah bertanggung jawab untuk mempublikasikan hasil pemeriksaan dari BPK RI atas LKPD kepada stakeholder. Informasi dari hasil pemeriksaan laporan keuangan yang disajikan tersebut bermanfaat bagi stakeholder sebagai dasar dalam pengambilan keputusan.

\section{Kinerja Keuangan Pemerintah Daerah}

Kinerja keuangan pemerintah daerah merupakan kemampuan suatu daerah dalam mengatur dan mengeksplorasi sumber-sumber keuangan asli daerah untuk memenuhi kebutuhannya. Hal ini guna memberikan support atas pelaksanaan sistem pemerintahan, pembangunan daerah dan pelayanan kepada masyarakat, sehingga dapat mandiri sepenuhnya dan tidak tergantung kepada pemerintah pusat serta memiliki keleluasaan dalam penggunaan dana yang ditujukan untuk kepentingan masyarakat daerah sesuai dengan regulasi yang ditentukan (Syamsi dalam Tarmizi, Khairudin, \& Jayadi, 2014).

Menurut Mardiasmo (2002, p. 121) pengukuran terhadap kinerja keuangan pemerintah daerah perlu dilakukan. Hal ini untuk memenuhi 3 (tiga) tujuan yaitu memperbaiki kinerja pemerintah daerah, membantu dalam mengalokasikan sumber daya dan membuat keputusan serta memperbaiki komunikasi antar dan mewujudkan pertanggungjawaban public. Kinerja keuangan pemerintah daerah dapat diukur dengan menganalisis rasio keuangan terhadap APBD antara lain derajat desentralisasi, rasio kemandirian, rasio efektivitas dan rasio pertumbuhan keuangan daerah.

\section{Kinerja Penyelenggaraan Pemerintahan Daerah}

Sesuai dengan Pasal 1 Permendagri No.73/2009, Kinerja Penyelenggaraan Pemerintahan Daerah (KPPD) adalah capaian atas penyelenggaraan urusan pemerintah daerah yang diukur dari input, process, output, result, benefit, dan/atau impact. LPPD merupakan laporan hasil penyelenggaraan pemerintahan daerah dalam periode I (satu) tahun anggaran sesuai Rencana Kerja Pembangunan Daerah (RKPD) yang disampaikan kepada Pemerintah Pusat oleh Kepala Daerah.

Kinerja tata kelola pemerintah daerah yang tertuang di dalam LPPD perlu dievaluasi (Sedyaningsih \& Zaky, 2015). Berdasarkan Peraturan Pemerintah No.6 Tahun 2008 menyatakan bahwa Evaluasi Penyelenggaraan Pemerintahan Daerah (EPPD) salah satunya adalah Evaluasi Kinerja Penyelenggaraan Pemerintahan Daerah (EKPPD). EKPPD merupakan proses pengumpulan dan analysis data yang dilakukan secara sistematis terhadap KPPD dengan menggunakan sistem pengukuran kinerja, yang teknisnya diatur dalam Peraturan Menteri Dalam Negeri No. 73 Tahun 2009.

Hasil dari EKPPD berupa Laporan Hasil Pemeringkatan dan status provinsi dan kabupaten/kota secara nasional berisi skor yang menunjukkan status dalam penyelenggaraan pemerintahan daerah. Hasil EKPPD tahunan digunakan oleh pemerintah sebagai acuan untuk melakukan pembinaan, pengawasan, dan kebijakan pemerintah dalam penyelenggaraan otonomi atau pembentukan, penghapusan/ penggabungan daerah otonom. (Menteri Dalam Negeri, 2009).

\section{Audit Sektor Publik}

Menurut Peraturan BPK-RI No.1 Tahun 2017 tentang Standar Pemeriksaan Keuangan Negara yang dimaksud dengan pemeriksaan (auditing) adalah proses identifikasi masalah, analysis, dan evaluasi yang dilakukan secara independent, objective, dan professional sesuai dengan auditing standard, untuk menilai kebenaran, kecermatan, credibility, dan keandalan informasi dalam pengelolaan dan tanggung jawab keuangan negara. Sedangkan audit pada organisasi public sector merupakan suatu proses sistematik yang dilakukan secara objektif dalam pengujian keakuratan dan kelengkapan dari informasi dalam suatu laporan keuangan organisasi public sector yang telah disajikan (Bastian, 2014, p. 4).

\section{Opini Audit BPK RI}

Opini audit menurut Undang-Undang No.15 Tahun 2004 adalah pernyataan profesional dari auditor berupa kesimpulan terkait tingkat kewajaran informasi yang tersaji di dalam laporan keuangan. Tingkat kewajaran dari informasi yang disajikan tersebut didasarkan pada (1) Standar Akuntansi Pemerintahan, (2) Pengungkapan yang cukup, (3) Kepatuhan terhadap peraturan perundang-undangan, dan (4) Efektivitas 
Sistem Pengendalian Internal (SPI) (Heriningsih, 2015). Undang-Undang No.15 Tahun 2004 menyatakan bahwa terdapat 4 (empat) jenis opini audit yang diberikan oleh BPK RI atas hasil pemeriksaan LKPD yaitu:

a. Unqualified opinion (Opini WTP)

Unqualified opinion adalah opini yang menunjukkan bahwa pemerintah telah menyajikan semua pos (akun) dalam laporan keuangan secara wajar. selain itu juga tidak terdapat salah saji yang material, dan tidak terdapat penyimpangan terhadap standar akuntansi atau prinsip akuntansi. Opini WTP merupakan pendapat yang paling tinggi dilihat dari kualitas laporan keuangan yang disajikan (Mahmudi, 2016, pp. 40-41).

b. Qualified opinion (Opini WDP)

Qualified opinion menunjukan sebagian besar pos dalam laporan keuangan telah disajikan secara wajar dalam artian terbebas dari salah saji material dan sesuai dengan standar akuntansi atau prinsip akuntansi, tetapi ada beberapa pos tertentu yang disajikan secara tidak wajar (Mahmudi, 2016, p. 41).

c. Adversed opinion (Opini TW)

Adversed opinion menunjukkan laporan keuangan yang diperiksa menyajikan pos-pos yang didalamnya terdapat salah saji yang material dan tidak sesuai dengan standar akuntansi. Keadaan seperti ini disebabkan oleh buruknya SPI dan sistem akuntansi yang ada (Mahmudi, 2016, p. 41). Sementara menurut Ikhsan, Noch, Ningsih, \& Hamdani (2015, p. 262) opini WDP diberikan ketika laporan keuangan dianggap wajar dalam hal yang material, namun terdapat suatu penyimpangan atau kurang lengkap pada pos tertentu, sehingga harus dikecualikan. Pengecualian pada pos tertentu ini mungkin saja terjadi apabila bukti kurang cukup/ lengkap, ruang lingkup dibatasi dan terdapat penyimpangan dalam penerapan prinsip akuntansi yang berlaku umum (SAP).

d. Disclaimer opinion (TMP)

Disclaimer opinion adalah opini yang menunjukkan bahwa auditor tidak menyatakan pendapat atas laporan keuangan. Menurut Mahmudi (2016, p. 41) Disclaimer opinion diberikan oleh auditor karena dua alasan, yaitu auditor terganggu independensinya dan dibatasi untuk mengakses data tertentu.

\section{METODE PENELITIAN}

\section{Data dan Sampel Penelitian}

Penelitian ini merupakan penelitian kuantitatif komparatif, sesuai dengan tujuan yang ingin dicapai dalam penelitian ini yaitu menganalisis perbedaan kinerja pemerintah daerah antara yang memperoleh opini WTP dengan opini Non WTP. Objek pada penelitian ini adalah kinerja keuangan daerah, kinerja penyelenggaraan pemerintahan daerah dan opini audit dari BPK RI. Jenis data yang digunakan dalam penelitian ini adalah data kuantitatif. Data Kuantitatif digunakan dalam penelitian ini bersumber dari data sekunder. Menurut Sekaran (2003, p. 222) "data sekunder mengacu pada informasi yang dikumpulkan oleh seseorang, dan bukan peneliti yang melakukan studi mutakhir." Data sekunder yang digunakan dalam penelitian ini yaitu (1) Ikhtisar Hasil Pemeriksaan Semester II (IHPS II) Tahun 2017, (2) Laporan APBD dan Realisasi APBD tahun 2014-2016, (3) Keputusan Menteri Dalam Negeri Tentang Peringkat dan Status Kinerja Penyelenggaraan Pemerintah Daerah Secara Nasional atas LPPD tahun 2014-2016.

Penafsiran pemerintah daerah yang menjadi populasi dalam penelitian ini adalah pemerintah kabupaten/kota se-Indonesia. Pemerintah kabupaten/kota se-Indonesia periode tahun 2014-2016 berjumlah 508, sehingga populasi dalam penelitian ini adalah 508 kabupaten/kota. Metode pengambilan sampel dalam penelitian ini adalah purposive sampling, menggunakan teknik judgement sampling. Dimana sampel yang diambil sesuai dengan kriteria yang ditetapkan oleh peneliti sebagai berikut:

Tabel 2.

Kriteria Pengambilan Sampel

\begin{tabular}{ll}
\hline Populasi kabupaten/kota se-Indonesia & 508 Kabupaten/Kota \\
\hline $\begin{array}{l}\text { Kabupaten/kota yang mendapatkan opini } \\
\text { dari BPK atas LKPD, lengkap tahun 2014- }\end{array}$ & 505 Kabupaten/Kota \\
2016 & \\
\hline $\begin{array}{l}\text { Kabupaten /kota yang memiliki Laporan } \\
\text { Realisasi APBD, lengkap tahun 2014-2016 }\end{array}$ & 496 Kabupaten/Kota \\
\hline
\end{tabular}


Kabupaten / kota yang memiliki Laporan

APBD, lengkap tahun 2014-2016

490 Kabupaten/Kota

Kabupaten / Kota yang memiliki skor

EKPPD, lengkap tahun 2014-2016 yang 465Kabupaten/Kota

lengkap

Kabupaten / kota yang mendapatkan opini

WTP (2014-2016) dan opini Non WTP

(2014-2016)

- Kabupaten / kota yang memperoleh opini 183 Kabupaten/Kota WTP

- Kabupaten / kota yang memperoleh opini 108 Kabupaten/Kota Non WTP

Sesuai dengan kriteria yang ditetapkan peneliti untuk keperluan pengujian uji beda, maka jumlah sampel harus diseimbangkan sebagai berikut:

- Opini Non WTP (2014-2016) 108 Kabupaten/Kota

- Opini WTP (2014-2016) 108 Kabupaten/Kota

Sampel yang memenuhi kriteria 216 Kabupaten/Kota

Sumber: Data diolah, 2018

Penelitian ini menganalisis perbedaan kinerja pemerintah kabupaten/ kota antara yang memperoleh opini WTP dengan opini Non WTP periode tahun 2014-2016. Variabel yang digunakan untuk mewakili kinerja pemerintah daerah adalah kinerja keuangan daerah dan kinerja penyelenggaraan pemerintahan dae-rah.

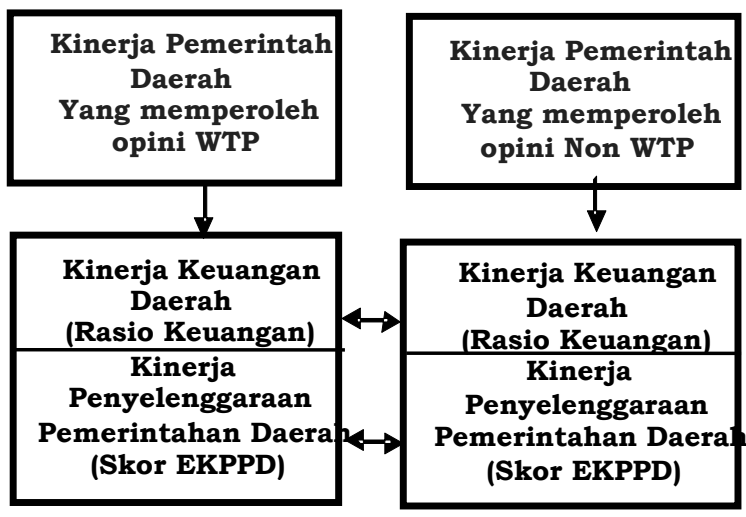

Sumber: Hasil Olahan Penulis (2018)

Gambar 1. Model Penelitian

\section{Hipotesis Penelitian}

Opini WTP yang diberikan BPK terhadap suatu daerah menunjukkan keberhasilan dalam hal pelaporan atas pengelolaan keuangan daerah tersebut. Sementara kinerja keuangan secara umum menggambarkan kemampuan suatu daerah dalam hal pengelolaan keuangannya. Salah satu alat yang digunakan untuk menganalisis kinerja pemerintah daerah dalam hal pengelolaan keuangan daerahnya adalah dengan menganalisis rasio keuangan terhadap APBD yang telah dilaksanakan.

Beberapa rasio yang dapat dikembangkan dari laporan realisasi APBD untuk menilai kinerja keuangan adalah rasio derajat desentralisasi, rasio kemandirian keuangan daerah, rasio efektivitas keuangan daerah dan rasio pertumbuhan pendapatan daerah. Rasio derajat desentralisasi dan kemandirian memperlihatkan kemampuan pemerintah daerah dalam memperoleh PAD dan seberapa besar kontribusi PAD tersebut dalam penyelenggaraan desentralisasi. Rasio efektivitas keuangan daerah memperlihatkan kemampuan pemerintah daerah dalam merealisasikan anggaran pendapatan daerah. Sementara rasio pertumbuhan pendapatan memperlihatkan kemampuan pemerintah daerah dalam meningkatkan realisasi pendapatan daerah dari tahun ke tahun.

Keberhasilan pelaporan pengelolaan keuangan daerah harusnya juga mencerminkan keberhasilan dalam pengelolaan keuangan daerah tersebut. Didukung hasil penelitian Masdiantini \& Erawati (2016) yang 
menyatakan bahwa adanya pengaruh positif signifikan opini audit BPK pada kinerja keuangan pemerintah kabupaten/kota se-Bali. Artinya semakin baik opini audit yang diberikan oleh BPK atas LKPD, maka seharusnya semakin baik pula kinerja pemerintah daerah dalam pengelolaan keuangannya. Dengan kata lain, pemerintah daerah yang memiliki opini WTP akan memiliki kinerja yang lebih baik dibandingkan dengan pemerintah daerah yang memperoleh opini Non WTP.

Hasil penelitian Khairudin (2013) menyimpulkan bahwa kinerja keuangan pemerintah kabupaten/kota se-Indonesia yang beropini WTP lebih baik dan berbeda secara signifikan dibandingkan dengan yang beropini Non WTP. Begitu juga dengan penelitian Tarmizi, Khairudin, \& Jayadi (2014) yang menyimpulkan bahwa kinerja keuangan pemerintah daerah Kota Bandar Lampung setelah opini WTP berbeda dengan sebelum opini WTP, yang artinya kinerja keuangan pemerintah daerah Kota Bandar Lampung setelah memperoleh opini WTP lebih baik dibandingkan dengan sebelum memperoleh opini WTP. Berdasarkan uraian di atas, maka dapat dirumuskan hipotesis sebagai berikut:

H1: KINERJA KEUANGAN PEMERINTAH KABUPATEN/KOTA YANG MEMPEROLEH OPINI WTP BERBEDA DARI YANG MEMPEROLEH OPINI NON WTP.

Opini audit menurut Undang-Undang Nomor 15 Tahun 2004 merupakan pernyataan profesional dari auditor berupa kesimpulan terkait tingkat kewajaran informasi yang disajikan dalam laporan keuangan. Opini WTP yang diberikan BPK terhadap suatu daerah menunjukkan keberhasilan dalam hal pelaporan atas pengelolaan keuangan daerah tersebut. EKPPD merupakan evaluasi terhadap Kinerja Penyelenggaraan Pemerintahan Daerah (KPPD).

Hasil dari EKPPD atas LPPD tahun 2016 berdasarkan Keputusan Menteri Dalam Negeri Nomor 100 53 Tahun 2018, Kab. Sidoarjo memperoleh status ST dan meraih peringkat paling tinggi secara nasional dalam kategori pemerintah kabupaten. Begitu juga dengan kota Malang memperoleh status ST dan meraih peringkat paling tinggi secara nasional dalam kategori pemerintah kota. Kab. Sidoarjo dan Kota Malang juga memperoleh opini WTP dari BPK RI atas audit LKPD tahun 2016 (Badan Pemeriksa Keuangan Republik Indonesia, 2018). Fenomena di atas menunjukkan adanya keberhasilan dalam pelaporan keuangan pemerintah daerah dengan perolehan opini WTP turut menunjang dalam hal keberhasilan kinerja penyelenggaraan pemerintahan daerah.

Keberhasilan pelaporan pengelolaan keuangan daerah idealnya juga mencerminkan keberhasilan dalam pengelolaan keuangan daerah tersebut. Keberhasilan dalam pelaporan dan pengelolaan keuangan tentunya juga akan berdampak positif terhadap penyelenggaraan pemerintahan daerah. Pemerintah yang memiliki pengelolaan keuangan yang baik serta didukung dengan kehandalan dalam pelaporannya akan diikuti dengan keberhasilan dalam kinerja penyelenggaraan pemerintahan daerah. Artinya kinerja penyelenggaraan pemerintahan daerah yang memperoleh opini WTP berbeda dengan yang memperoleh opini Non WTP.

Hal ini sejalan dengan penelitian Sutopo, Wulandari, Adiati, \& Saputra (2017) yang menyatakan bahwa opini auditor memiliki hubungan positif dengan kinerja penyelenggaraan pemerintahan daerah, dengan demikian pemerintah daerah yang memiliki opini audit yang lebih baik cenderung memiliki kinerja yang lebih tinggi. Hasil penelitian Yasmin (2016) menyatakan bahwa kinerja penyelenggaraan pemerintahan daerah pada pemerintah kabupaten/kota yang memperoleh opini WTP berbeda secara signifikan dengan pemerintah kabupaten/kota yang memperoleh opini Non WTP. Berdasarkan uraian di atas dapat dirumuskan hipotesis sebagai berikut:

H2: KINERJA PENYELENGGARAAN PEMERINTAHAN DAERAH PADA PEMERINTAH KABUPATEN/KOTA YANG MEMPEROLEH OPINI WTP BERBEDA DARI YANG MEMPEROLEH OPINI NON WTP.

\section{Definisi Operasional Variabel \\ Opini Audit (X)}

Opini audit menurut Undang-Undang Nomor 15 Tahun 2004 adalah pernyataan profesional dari auditor berupa kesimpulan terkait tingkat kewajaran informasi yang disajikan dalam laporan keuangan. Opi$\mathrm{ni}$ audit dalam penelitian ini merupakan variabel independen, dimana pengukuran variabel bebas bersifat non metrik menggunakan skala nominal (Ghozali, 2016, p. 192). Skala nominal menyatakan kategori dari suatu subyek, dalam hal ini opini audit. Variabel opini audit dalam penelitian ini dibagi menjadi dua kategori yaitu WTP (opini WTP) dan Non WTP (opini WDP, TW dan TMP). Kedua kategori ini diberi kode 
angka, untuk kategori WTP diberi kode 1 dan Non WTP diberi kode 0 . Angka 1 dan 0 hanya sebagai cara untuk mengelompokkan subyek kedalam kelompok yang berbeda (Ghozali, 2015, p. 10).

\section{Kinerja Keuangan Daerah (Y1)}

Variabel kinerja keuangan daerah diukur dengan menggunakan rasio keuangan yaitu:

1. Rasio Derajat Desentralisasi

Rasio derajat desentralisasi merupakan perbandingan antara total PAD dengan total pendapatan daerah. Rasio ini menunjukkan derajat kontribusi PAD terhadap total pendapatan daerah. Semakin tinggi kontribusi PAD maka semakin tinggi kemampuan pemerintah daerah dalam penyelenggaraan desentralisasi. Rasio ini dirumuskan sebagai berikut (Mahmudi, 2016, p. 140):

\section{PAD}

Derajat Desentralisasi $=-\quad \times 100 \%$

\section{Total Pendapatan}

Daerah

Kriteria tingkat desentralisasi fiskal dalam penilaian kinerja keuangan dapat dilihat pada tabel sebagai berikut:

Tabel 3

Kriteria Tingkat Derajat Desentralisasi

\begin{tabular}{cc}
\hline Derajat Desentralisasi & Kriteria \\
\hline $0 \%-10 \%$ & Sangat Kurang \\
$>10 \%-20 \%$ & Kurang \\
$>20 \%-30 \%$ & Sedang \\
$>30 \%-40 \%$ & Cukup \\
$>40 \%-50 \%$ & Baik \\
$>50 \%$ & Sangat Baik \\
\hline
\end{tabular}

Sumber: Tim Litbang Depdagri dalam Bisma \& Susanto (2010)

2. Rasio Kemandirian Keuangan Daerah

Rasio kemandirian keuangan daerah merupakan perbandingan total PAD dengan jumlah pendapatan transfer baik dari pusat maupun provinsi serta pinjaman daerah. Rasio ini dapat dirumuskan sebagai berikut (Mahmudi, 2016, p. 140)

\section{Rasio Kemandirian $=$}

Transfer Pusat+Provinsi+Pinjaman

Terkait pelaksanaan otonomi daerah, tingkat kemandirian pemerintah daerah dan pola hubungan diantara pemerintah daerah dan pemerintah pusat dapat dilihat pada tabel sebagai berikut:

Tabel 4

Pola Hubungan dan Tingkat Kemandirian Daerah

\begin{tabular}{ccc}
\hline $\begin{array}{c}\text { Kemampuan } \\
\text { Daerah }\end{array}$ & $\begin{array}{c}\text { Kemandirian } \\
(\mathbf{\%})\end{array}$ & $\begin{array}{c}\text { Pola } \\
\text { Hubungan }\end{array}$ \\
\hline Rendah sekali & $0-25$ & Instruktif \\
Rendah & $25-50$ & Konsultatif \\
Sedang & $50-75$ & Partisipatif \\
Tinggi & $75-100$ & Delegatif \\
\hline
\end{tabular}

Sumber: Halim dalam Khairudin (2013)

3. Rasio Efektivitas Keuangan Daerah

Rasio efektivitas keuangan daerah menunjukkan kemampuan pemerintah daerah dalam merealisasikan pendapatan daerah sesuai dengan yang telah dianggarkan. Rasio efektivitas dapat dirumuskan sebagai berikut (Mahsun, 2016, p. 187): 
rian keuangan daerah untuk periode tahun 2014-2016 pada hasil statistik deskriptif menunjukkan pemerintah kabupaten/kota yang memperoleh opini WTP lebih baik dibandingkan dengan yang memperoleh opini Non WTP dengan selisih nilai mean 13,86\%, sehingga dapat dikatakan pemerintah kabupaten/kota yang memperoleh opini Non WTP memiliki tingkat ketergantungan yang tinggi kepada pihak ekstern. Walaupun jika dilihat dari kriteria, baik pemerintah kabupaten/kota yang memperoleh opini WTP ataupun Non WTP masuk dalam kategori yang sama untuk aspek kemandirian keuangan daerahnya yaitu rendah sekali atau memiliki pola hubungan instruktif.

Hasil analisis dalam aspek efektivitas keuangan daerah periode tahun 2014-2016 menunjukkan bahwa dalam hal merealisasikan pendapatan daerah, baik pemerintah kabupaten/kota yang memperoleh opini WTP ataupun Non WTP masuk dalam kategori yang sama yaitu sangat efektif . Namun jika dilihat dari nilai mean rasio efektivitas dapat disimpulkan bahwa pemerintah kabupaten/kota yang memperoleh opini WTP lebih baik dalam hal merealisasikan pendapatan daerahnya dibandingkan dengan pemerintah kabupaten/kota yang memperoleh opini Non WTP.

Kinerja keuangan dari aspek pertumbuhan pendapatan daerah periode tahun 2014-2016 menunjukkan baik pemerintah kabupaten/kota yang memperoleh opini WTP ataupun Non WTP mengalami peningkatan yang positif untuk pendapatan daerahnya dari tahun sebelumnya. Walaupun dari nilai mean rasio pertumbuhan menunjukkan bahwa pemerintah kabupaten/kota yang memperoleh opini Non WTP lebih baik dibandingkan dengan yang memperoleh opini WTP.

Hasil analisis perbandingan kinerja penyelenggaraan pemerintahan daerah pada hasil statistik deskriptif, menunjukkan nilai mean skor EKPPD periode tahun 2014-2016 pemerintah kabupaten/kota yang memperoleh opini WTP lebih tinggi dibandingkan yang memperoleh opini Non WTP, dengan selisih nilai 0,63. Berdasarkan Skor tersebut, pemerintah kabupaten/kota yang memperoleh opini WTP mendapatkan status ST (Sangat Tinggi) dan yang memperoleh opini Non WTP mendapatkan satus T (Tinggi). Artinya kinerja pemerintah kabupaten/kota yang memperoleh opini WTP lebih baik dibandingkan dengan yang memperoleh opini Non WTP dari sisi penyelenggaraan pemerintahan daerah.

\section{Uji Normalitas Data}

Uji normalitas data dalam penelitian ini menggunakan uji statistik Kolmogorov-Smirnov (K-S) dengan bantuan program SPSS 23 untuk mengetahui apakah data tiap variabel berdistribusi normal. Data berdistribusi secara normal apabila signifikansinya lebih besar dari tingkat signifikansi yang sudah ditentukan $(\geq 0,05)$ sehingga $\mathrm{H0}$ diterima. Sebaliknya data berdistribusi tidak normal apabila signifikansi uji lebih kecil dari nilai signifikansi $(<0,05)$ sehingga $\mathrm{H} 0$ ditolak (Ghozali, 2016, pp. 30-31). Uji normalitas dilakukan untuk menentukan alat uji statistik apa yang akan digunakan dalam pengujian hipotesis. Berikut hasil uji normalitas dari tiap variabel:

Tabel 7

Hasil uji Normalitas Kolmogorov-Smirnov

\begin{tabular}{|c|c|c|c|c|c|c|}
\hline \multirow{2}{*}{ Variabel } & \multicolumn{3}{|c|}{ WTP } & \multicolumn{3}{|c|}{ Non WTP } \\
\hline & Statistic & $d f$ & Sig. & Statistic & $d f$ & Sig. \\
\hline $\begin{array}{l}\text { Rasio } \\
\text { Keuangan }\end{array}$ & 0,196 & 108 & 0,000 & 0,105 & 108 & 0,005 \\
\hline $\begin{array}{l}\text { Skor } \\
\text { EKPPD }\end{array}$ & 0,119 & 108 & 0,001 & 0,093 & 108 & 0,022 \\
\hline
\end{tabular}

Hasil uji normalitas yang ditunjukkan oleh tabel 7, memperlihatkan kedua variabel dalam penelitian ini yaitu rasio keuangan yang mewakili kinerja keuangan dan skor EKPPD yang mewakili kinerja penyelenggaraan pemerintahan daerah, baik yang memperoleh opini WTP maupun Non WTP memiliki tingkat signifikansi 0,000 dan nilainya jauh dibawah 0,05 sehingga $\mathrm{H} 0$ ditolak atau data tidak berdistribusi secara normal. Berdasarkan hasil uji normalitas, maka alat uji statistik parametrik yaitu Independent Sample tTest tidak dapat digunakan untuk pengujian hipotesis. Sebagai alternatif karena data tidak berdistribusi normal maka akan digunakan alat uji statistik nonparametrik yaitu uji sta-tistik Mann-Whitney U Test (Ghozali, 2015, p. 132).

Alat uji statistik parametrik hanya dapat digunakan jika data yang digunakan baik un-tuk kabupaten/kota yang memperoleh opini WTP ataupun opini Non WTP berdistribusi normal. Jika hanya salah 
satunya saja yang berdistribusi normal dan yang satunya tidak berdistribusi normal, maka alat uji statistik parametrik juga tidak dapat digunakan dan alternatif alat uji yang digunakan adalah statistik nonparametrik 'Mann-Whitney U Test'.

\section{Analisis Data}

Tabel 8

Hasil Pengujian Mann-Whitney U Test

\begin{tabular}{cccc}
\hline Variabel & $\begin{array}{c}\text { Asymp. Sig. } \\
\text { (2-tailed) }\end{array}$ & \multicolumn{2}{c}{ Mean Rank } \\
\cline { 3 - 4 } & Opini & $\begin{array}{c}\text { Opini Non } \\
\text { WTP }\end{array}$ \\
\hline $\begin{array}{c}\text { Rasio } \\
\text { Keuangan }\end{array}$ & 0,000 & 150.39 & 66.61 \\
\hline $\begin{array}{c}\text { Skor } \\
\text { EKPPD }\end{array}$ & 0,000 & 149.69 & 67,31
\end{tabular}

Sumber: Output SPSS 23 - Hasil Uji Mann-Whitney U Test (Data diolah, 2018)

Tabel 8 menunjukkan nilai Asymp.Sig. (2-tailed) untuk rasio keuangan yang mewakili kinerja keuangan pemerintah daerah sebesar $0,000<$ alpha $(0,05)$, dengan demikian $\mathrm{H} 1$ diterima. Nilai mean rank rasio keuangan pemerintah kabupaten / kota yang memperoleh opini WTP lebih besar dibandingkan rasio keuangan pemerintah kabupaten / kota yang memperoleh opini Non WTP dengan selisih nilai sebesar 83,78. sehingga dapat dikatakan bahwa kinerja keuangan pemerintah kabupaten / kota yang memperoleh opini WTP tidak hanya berbeda, tetapi juga lebih baik dibandingkan dengan kinerja keuangan pemerintah kabupaten / kota yang memperoleh opini Non WTP periode tahun 2014-2016. Hasil pengujian untuk skor EKPPD yang mewakili kinerja penyelenggaraan pemerintahan daerah pada tabel 8, menunjukkan nilai Asymp.Sig (2-tailed) sebesar 0,000 kurang dari 5\% atau 0,05, sehingga H2 diterima. Nilai Mean rank skor EKPPD untuk pemerintah kabupaten/kota yang memperoleh opini WTP lebih besar dibandingkan dengan pemerintah kabupaten/kota yang memperoleh opini Non WTP. Dengan demikian, kinerja penyelenggaraan pemerintahan daerah pada pemerintah kabupaten/kota yang memperoleh opini WTP berbeda secara signifikan dan lebih baik dari yang memperoleh opini Non WTP.

\section{Pembahasan}

\section{Opini Audit Terhadap Kinerja Keuangan Daerah (Hipotesis 1)}

Hipotesis 1 bertujuan untuk membuktikan bahwa terdapat perbedaan kinerja keuangan pemerintah kabupaten/ kota yang memperoleh opini WTP dengan pemerintah kabupaten/ kota yang memperoleh opini Non WTP. Hasil pengujian menunjukkan nilai Asymp.Sig. (2-tailed) sebesar 0,000 < alpha (0,05), artinya kinerja keuangan pemerintah kabupaten/kota se-Indonesia yang memperoleh opini WTP berbeda secara signifikan dari yang memperoleh opini Non WTP. Nilai mean rank kinerja keuangan pemerintah kabupaten / kota yang memperoleh opini WTP lebih besar dibandingkan kinerja keuangan pemerintah kabupaten / kota yang memperoleh opini Non WTP, sehingga perbedaan ini dapat diartikan bahwa kinerja keuangan pemerintah kabupaten / kota yang memperoleh opini WTP lebih baik dibandingkan dengan kinerja keuangan pemerintah kabupaten / kota yang memperoleh opini Non WTP periode tahun 2014-2016.

Hasil penelitian ini sejalan dengan penelitian Khairudin (2013), yang menyatakan bahwa kinerja keuangan pemerintah kabupaten/kota se-Indonesia yang beropini WTP lebih baik dan berbeda secara signifikan dibandingkan dengan yang beropini Non WTP. Hasil penelitian ini juga sejalan dengan penelitian Tarmizi, Khairudin, \& Jayadi (2014) yang menyimpulkan bahwa kinerja keuangan pemerintah daerah Kota Bandar Lampung setelah opini WTP berbeda dengan sebelum opini WTP. Namun tidak sejalan dengan penelitian Dary \& Yahya (2016) yang menunjukkan bahwa kinerja keuangan PAD periode opini Non WTP tidak berbeda dengan kinerja keuangan PAD periode opini WTP.

Perbedaan kinerja keuangan juga terlihat dari perolehan persentase kinerja keuangan berdasarkan statistik deskriptif. Pemerintah kabupaten/kota yang memperoleh opini WTP memperolehan persentase yang lebih tinggi sebesar 6,5\% dari pemerintah kabupaten/kota yang memperoleh opini Non WTP. Secara rinci indikator rasio keuangan yang digunakan menunjukkan bahwa pemerintah kabupaten/kota yang memperoleh opini WTP dari aspek kemandirian daerah, kontribusi PAD/ derajat desentralisasi dan efekti- 
vitas keuangan daerah memperoleh persentase yang lebih tinggi dibandingkan dengan pemerintah kabupaten/kota yang memperoleh opini Non WTP. Sementara dari aspek pertumbuhan pendapatan daerah pemerintah kabupaten/kota yang memperoleh opini Non WTP lebih baik dibandingkan dengan pemerintah kabupaten/kota yang memperoleh opini WTP. Walaupun pertumbuhan pemerintah kabupaten/kota yang memperoleh opini Non WTP lebih baik dibandingkan dengan yang memperoleh opini WTP tetapi diduga hal tersebut dikarenakan presentasi pendapatan yang berasal dari pemerintah pusat atau pihak ekstern mendominasi lebih dari $80 \%$.

Menurut Ghozali \& Chariri, (2014, p. 439) stakeholder theory mengatakan bahwa perusahaan atau organisasi merupakan entitas yang tidak hanya beroperasi untuk kepentingannya sendiri tetapi juga harus memberi manfaat kepada stakeholder. Mahmudi (2016, pp. 7-8) menyatakan yang menjadi stakeholder bagi pemerintah daerah adalah masyarakat, investor, pegawai pemerintah daerah, penyedia barang dan jasa, DPRD, badan pengawas dan advokasi, rating agencies, pemerintah pusat, pemerintah daerah lain, lembaga-lembaga internasional dan manajemen.

Penelitian ini menyimpulkan bahwa opini yang diberikan oleh BPK RI menggambarkan kemampuan pemerintah daerah dalam mengelola keuangan daerahnya. Semakin baik opini audit yang diberikan oleh BPK RI, maka akan semakin baik pula kinerja keuangan pemerintah daerahnya, sehingga opini BPK dapat dijadikan acuan dalam menilai kinerja keuangan pemerintah daerah. Hal ini menunjukkan bahwa opini audit yang diperoleh pemerintah daerah, dapat bermanfaat bagi stakeholder sebagai informasi untuk menilai kinerja keuangan pemerintah daerah yang dapat digunakan untuk keperluan dalam pengambilan keputusan.

Jensen \& Meckling (1976) menjelaskan agency theory sebagai hubungan keagenan, dimana terdapat kontrak antara principal dan agent untuk melakukan suatu jasa atas nama principal yang disertai dengan pemberian wewenang pada agent untuk membuat keputusan yang terbaik bagi principal. Principal berhak menuntut pertanggungjawaban atas wewenang yang diberikan kepada agent. Salah satu masalah keagenan yang muncul dalam hubungan keagenan adalah asimetri informasi. Asimetri informasi merupakan keadaan dimana tidak semua informasi/ keadaan diketahui kedua belah pihak, dalam artian principal tidak mengetahui informasi secara lengkap seperti agent (Hendriksen \& Breda, 2000, p. 222). Untuk mendapatkan informasi yang dibutuhkan dalam memonitor kinerja agents dan untuk menentukan struktur insentif serta monitoring yang efisien, principal sendiri harus mengeluarkan biaya yang dikenal dengan agency cost (Petrie, 2002).

Bentuk pertanggungjawaban pemerintah daerah sebagai agent kepada masyarakat (DPRD) sebagai principal dalam hal pengelolaan keuangan daerah dapat dilihat dari kinerja keuangannya. Berdasarkan hasil penelitian, pemerintah daerah yang memperoleh opini WTP memiliki kinerja yang lebih baik dibandingkan dengan pemerintah daerah yang memiliki opini Non WTP, sehingga dapat disimpulkan bahwa pertanggungjawaban pemerintah daerah yang memperoleh opini WTP dalam hal pengelolaan keuangan daerah lebih baik dibandingkan dengan pemerintah daerah yang memperoleh opini Non WTP. Selain itu, pelaksanaan audit oleh BPK RI sebagai wujud dari agency cost berjalan seperti yang diharapkan karena opini yang dihasilkan dapat digunakan dalam memonitor kinerja agent/ pemerintah daerah.

\section{Opini Audit Terhadap Kinerja Penyelenggaraan Pemerintahan Daerah (Hipotesis 2)}

Hipotesis 2 bertujuan untuk membuktikan bahwa terdapat perbedaan kinerja penyelenggaraan pemerintahan daerah antara pemerintah kabupaten/ kota yang memperoleh opini WTP dengan pemerintah kabupaten/ kota yang memperoleh opini Non WTP. Hasil pengujian menunjukkan nilai Asymp.Sig. (2tailed) sebesar 0,000 < alpha $(0,05)$, dimana nilai mean rank kinerja penyelenggaraan pemerintahan daerah pada pemerintah kabupaten / kota yang memperoleh opini WTP lebih besar dibandingkan kinerja penyelenggaraan pemerintahan daerah pada pemerintah kabupaten / kota yang memperoleh opini Non WTP. Artinya, kinerja penyelenggaraan pemerintahan daerah pada pemerintah kabupaten/kota yang memperoleh opini WTP berbeda secara signifikan dan lebih baik dari yang memperoleh opini Non WTP. Hasil penelitian ini sejalan dengan penelitian Yasmin (2016) yang menyatakan bahwa kinerja penyelenggaraan pemerintahan daerah pada pemerintah kabupaten/kota yang memperoleh opini WTP berbeda secara signifikan dengan pemerintah kabupaten/kota yang memperoleh opini Non WTP. Namun tidak sejalan dengan hasil penelitian Heriningsih (2015) yang menyatakan bahwa tidak terdapat perbedaan antara kinerja penyelenggaraan pemerintahan daerah yang memperoleh opini WTP dan yang memperoleh opini selain WTP. 
Keberhasilan dalam penyelenggaraan pemerintahan yang memperoleh opini WTP memperoleh skor yang tinggi dalam penilaian indeks capaian kinerja dan kesesuaian materi. Artinya dalam hal pengelolaan keuangan daerah, perencanaan pembangunan daerah, pemberian fasilitas terhadap partisipasi masyarakat, pelaksanaan urusan pendidikan dan urusan kesehatan yang mengacu kepada kesejahteraan masyarakat, pemerintah kabupaten/kota yang memperoleh opini WTP lebih baik dibandingkan dengan pemerintah kabupaten/kota yang memperoleh opini Non WTP. Keselarasan antara kebijakan pemerintah daerah dengan kebijakan pemerintah, Ketaatan terhadap peraturan perundang-undangan, efektivitas perencanaan, penyusunan, pelaksanaan tata usaha, pertanggungjawaban, dan pengawasan APBD serta transparansi dalam pemanfaatan alokasi, pencairan, penyerapan DAU, DAK dan bagi hasil juga lebih baik dibandingkan dengan pemerintah kabupaten/kota yang memperoleh opini Non WTP.

Teori keagenan menurut Halim \& Abdullah (2006) adalah teori yang membahas hubungan antara dua pihak yang melakukan kesepakatan atau kontrak, yakni pihak pemberi wewenang (principal) dan pihak penerima wewenang (agent). Dengan kata lain dalam hubungan ini terjadi pendelegasian wewenang dari agent kepada principal. Hubungan ini menuntut adanya pertanggungjawaban dari agent atas pendelegasian wewenang yang diberikan oleh principal. Salah satu masalah keagenan yang muncul dalam hubungan keagenan adalah asimetri informasi, keadaan dimana principal tidak mengetahui informasi secara lengkap seperti agent (Hendriksen \& Breda, 2000, p. 222). Untuk memperoleh informasi yang dibutuhkan dalam memonitor kinerja agents, principal sendiri harus mengeluarkan biaya yang disebut agency cost (Petrie, 2002) . Jensen \& Meckling (1976) mengartiakan agency cost sebagai biaya yang dikeluarkan oleh principal dalam rangka melakukan pengawasan terhadap agent.

Kinerja penyelenggaraan pemerintahan daerah berupa skor dan status EKPPD merupakan bentuk pertanggungjawaban yang diberikan oleh pemerintah daerah dalam penyelenggaraan pemerintahan daerah. Hasil penelitian menunjukkan bahwa pemerintah daerah yang memperoleh opini WTP memiliki pertanggungjawaban penyelenggaraan pemerintahan yang lebih baik dibandingkan dengan pemerintah daerah yang memperoleh opini Non WTP. Selain itu, hasil penelitian ini juga menunjukkan bahwa pelaksanaan audit oleh BPK RI sebagai wujud dari agency cost berjalan sesuai harapan, karena opini yang dihasilkan dapat digunakan dalam memonitor kinerja penyelenggaraan pemerintahan daerah/ kinerja agent.

Stakeholder menurut Gray (2001) merupakan pihak-pihak yang memiliki kepentingan pada perusahaan atau organisasi. Stakeholder theory mengatakan bahwa perusahaan atau organisasi merupakan entitas yang beroperasi tidak hanya untuk kepentingannya sendiri tetapi juga harus memberi manfaat kepada stakeholder (Ghozali \& Chariri, 2014, p. 439). Para stakeholder bagi pemerintah daerah adalah masyarakat, investor, pegawai pemerintah daerah, penyedia barang dan jasa, DPRD, badan pengawas dan advokasi, rating agencies, pemerintah pusat, pemerintah daerah lain, lembaga-lembaga internasional dan manajemen (Mahmudi, 2016, pp. 7-8).

Berdasarkan hasil penelitian dapat dikatakan semakin baik opini audit yang diberikan oleh BPK, maka akan semakin baik pula kinerja penyelenggaraan pemerintahan daerahnya. Pengungkapan opini audit oleh BPK dapat menggambarkan kinerja penyelenggaraan pemerintahan daerah dan bermanfaat bagi pihak stakeholder karena dapat dijadikan acuan untuk menilai kinerja penyelenggaraan pemerintahan daerah yang digunakan sebagai informasi dalam pengambilan keputusan bagi stakeholder.

\section{SIMPULAN, KETERBATASAN DAN SARAN}

Berdasarkan hasil pengujian hipotesis dapat disimpulkan bahwa kinerja keuangan daerah pada pemerintah kabupaten/kota se-Indonesia yang memperoleh opini WTP berbeda secara signifikan dan lebih baik daripada pemerintah kabupaten/kota se-Indonesia yang memperoleh opini Non WTP. Kinerja penyelenggaraan pemerintahan daerah pada pemerintah kabupaten/kota se-Indonesia yang memperoleh opini WTP juga terbukti memiliki kinerja yang berbeda secara signifikan dan lebih baik daripada pemerintah kabupaten/kota se-Indonesia yang memperoleh opini Non WTP.

Dalam hal pengelolaan keuangan daerah, pemerintah kabupaten/kota yang memperoleh opini WTP memiliki persentase rasio keuangan yang lebih tinggi sebesar 6,5\% dari pemerintah kabupaten/kota yang memperoleh opini Non WTP. Walaupun secara persentase perbedaannya tidak terlalu mencolok tetapi berdasarkan pengujian statistik menunjukkan perbedaan yang signifikan. Sementara untuk penyelenggaraan pemerintahan daerah pada pemerintah kabupaten/kota yang memperoleh opini WTP berdasarkan statistik deskriptif menunjukkan nilai mean skor EKPPD periode tahun 2014-2016 yang lebih tinggi dibandingkan yang memperoleh opini Non WTP, dengan selisih nilai 0,63. Berdasarkan skor tersebut, pemerin- 
tah kabupaten/kota yang memperoleh opini WTP mendapatkan status ST (Sangat Tinggi) dan yang memperoleh opini Non WTP mendapatkan satus T (Tinggi). Artinya kinerja pemerintah kabupaten/kota yang memperoleh opini WTP lebih baik dibandingkan dengan yang memperoleh opini Non WTP dari sisi penyelenggaraan pemerintahan daerah. Hal ini juga sesuai dengan hasil pengujian secara statistik yang menunjukkan perbedaan yang signifikan antara pemerintah kabupaten/kota yang memperoleh opini WTP dengan yang memperoleh opini Non WTP.

Hasil penelitian ini juga memberikan implikasi secara teoritis maupun praktis. Beberapa implikasi teoritis berdasarkan hasil penelitian yaitu (1) temuan penelitian ini memberikan bukti empiris bahwa kinerja keuangan dan kinerja penyelenggaraan pemerintahan daerah pada pemerintah kabupaten/kota seIndonesia yang memperoleh opini WTP berbeda secara signifikan dan lebih baik daripada pemerintah kabupaten/kota se-Indonesia yang memperoleh opini Non WTP, (2) hasil penelitian menunjukkan bahwa pertanggungjawaban pemerintah daerah yang memperoleh opini WTP dalam pengelolaan keuangan maupun penyelenggaraan pemerintahan daerah lebih baik dibandingkan dengan yang memperoleh opini Non WTP, (3) hasil penelitian menunjukkan bahwa pelaksanaan audit oleh BPK RI sebagai wujud dari agency cost berjalan seperti yang diharapkan karena opini yang dihasilkan dapat digunakan dalam memonitor kinerja agent yaitu kinerja keuangan pemerintah daerah dan kinerja penyelenggaraan pemerintahan daerah. Secara praktis implikasi dari hasil penelitian ini memberikan gambaran terkait kinerja pemerintah daerah dari sisi pengelolaan keuangan dan penyelenggaraan pemerintahan pada pemerintah kabupaten/kota yang memperoleh opini WTP dan Non WTP untuk digunakan sebagai bahan evaluasi bagi pemerintah kabupaten/kota maupun pemerintah pusat.

Penelitian ini memiliki keterbatasan dimana data sampel untuk pemerintah kabupaten/kota yang memperoleh opini WTP didapatkan dengan cara judgment sampling dan diacak sebanyak 3 kali untuk penetapan sampel nya. Walaupun sampel yang ditetapkan mewakili setiap pulau di Indonesia namun besaran sampel pemerintah kabupaten/kota yang memperoleh opini WTP dari masing-masing pulau di Indonesia ini tidak proporsional. Berdasarkan hasil analisis deskriptif diketahui bahwa kinerja keuangan dari aspek derajat desentralisasi dan kemandirian daerah untuk pemerintah kabupaten/kota yang memperoleh opini WTP dan Non WTP masih kurang baik. Pemerintah kabupaten/kota sebaiknya lebih meningkatkan kontribusi PAD dengan menggali potensi PAD secara maksimal misalnya pemungutan PBB dan pajak reklame, serta potensi pada sektor pariwisata (objek wisata) dibeberapa daerah yang masih bisa ditingkatkan jika dikelola dengan baik.

Variabel yang digunakan untuk mewakili kinerja pemerintah daerah dalam penelitian ini adalah kinerja keuangan daerah dan kinerja penyelenggaraan pemerintahan daerah. Disarankan untuk penelitian selanjutnya dapat menggunakan variabel lain yang dapat mewakili kinerja pemerintah daerah, seperti kinerja instansi pemerintah daerah. Selain itu dalam penelitian ini besaran sampel pemerintah kabupaten/kota yang memperoleh opini WTP dari masing-masing pulau di Indonesia ini tidak proporsional. Bagi penelitian selanjutnya, untuk mendapatkan besaran sampel yang sesuai dengan proporsinya untuk tiap pulau di Indonesia, disarankan untuk menggunakan teknik cluster sampling (area sampling design).

\section{DAFTAR PUSTAKA}

Badan Pemeriksa Keuangan Republik Indonesia. (2018). Ikhtisar Hasil Pemeriksaan Semester II Tahun 2017.

Badan Pemeriksa Keuangan Republik Indonesia. (2017). Peraturan BPK-RI No.1 Tahun 2017 Tentang Standar Pemeriksaan Keuangan Negara.

Badan Pusat Statistik. (2018). Persentase Penduduk Miskin Menurut Kabupaten/Kota, 2015-2017. Badan Pusat Statistik.

Bastian, I. (2014). Audit Sektor Publik: Pemeriksaan Pertanggungawaban Pemerintah (3 ed.). Jakarta: Salemba Empat.

Bisma, I. D., \& Susanto, H. (2010, Desember ). Evaluasi Kinerja Keuangan Daerah Pemerintah Provinsi Nusa Tenggara Barat Tahun Anggaran 2003-2007. Ganec Swara , 75-86.

Dary, Y. W., \& Yahya, M. (2016). Analisis Perbedaan Kinerja Keuangan Pendapatan Asli Daerah Periode Opini Non WTP dan Periode Opini WTP. Jurnal Ilmiah Mahasiswa Ekonomi Akuntansi , 1, 60-73.

Dianto, A. (2017, January). Uji Normalitas Dua Sampel (Mean) Menggunakan SPSS . Retrieved Juli 2018, from Aksiomatik Metodologi Penelitian dan Statistika https://aksiomatik.wordpress.com/2017/01/29/uji-normalitas-dua-sampel-mean-menggunakanspss/ 
Ghozali, I. (2016). Aplikasi Analisis Multivariete dengan Program IBM SPSS 23 (8 ed.). Semarang: Badan Penerbit Universitas Diponegoro.

Ghozali, I. (2016). Desain Penelitian Kuantitatif dan Kualitatif untuk Akuntansi, Bisnis, dan Ilmu Sosial Lainnya. Semarang: Yoga Pratama.

Ghozali, I. (2015). Statistik Non Parametrik - Teori dan Aplikasi dengan program IBM SPSS 23. Semarang: Universitas Diponegoro.

Ghozali, I., \& Chariri, A. (2014). Teori Akuntansi (Edisi 4 ed.). Semarang: Badan Penerbit Universitas Diponegoro.

Grey, R. (2001). Thirty Years of Social Accounting, Reporting, and Auditing: What (if anything) have we learnt? Business Ethics: A European Review , 10, 9-15.

Halim, A. (2007). Akuntansi Sektor Publik - Akuntansi keuangan Daerah. Jakarta: Salemba Empat.

Halim, A., \& Abdullah, S. (2006). Hubungan dan Masalah Kegenan di Pemerintah Daerah. Jurnal Akuntansi Pemerintahan , 53-64.

Hendriksen, E. S., \& Breda, M. F. (2000). Teori Akunting. Jakarta: Interaksara.

Heriningsih, S. (2015). Analisis Kinerja Penyelenggaraan Pemerintah Daerah Dan Tingkat Korupsi Dianalisis Dari Opini Audit. University Research Colloquium , 86-95.

Ikhsan, A., Noch, M. Y., Ningsih, H. T., \& Hamdani. (2015). Akuntansi Sektor Publik. Bandung: Citapustaka Media.

Jensen, M. C., \& Meckling, W. H. (1976). Theory of The Firm: Managerial Behavior, Agency Cost and Ownership structure. Journal of Financial Economics 3 , 305-360.

Khairudin. (2013). Does Financial Performance Of Local Government Influence On The Audit Agency Opinion? JURNAL Akuntansi \& Keuangan , 4, 33-54.

Mahmudi. (2016). Analisis Laporan Keuangan Pemerintah Daerah. YOGYAKARTA: UPP STIM YKPN.

Mahsun, M. (2016). Pengukuran Kinerja Sektor Publik. Yogyakarta: BPFE.

Mardiasmo. (2002). Akuntansi Sektor Publik. Yogyakarta: ANDI.

Masdiantini, P. R., \& Erawati, N. M. (2016). Pengaruh Ukuran Pemerintah Daerah, Kemakmuran, Intergovernmental Revenue, Temuan dan Opini Audit BPK Pada Kinerja Keuangan. E-Jurnal Akuntansi Universitas Udayana , 1150-1182.

Menteri Dalam Negeri Republik Indonesia. (1996). Keputusan Menteri Dalam Negeri. Nomor 690.900.327. 1996. Tentang Pedoman Penilaian dan Kinerja keuangan.

Menteri Dalam Negeri Republik Indonesia. (2009). Peraturan Menteri Dalam Negeri Nomor 73 Tahun 2009 Tentang Tatacara Pelaksanaan Evaluasi Kinerja Penyelenggaraan Pemerintahan Daerah.

Menteri Dalam Negeri Republik Indonesia. (2018). Keputusan Menteri Dalam Negeri Nomor 100 - 53 Tahun 2018 Tentang Peringkat dan Status Kinerja Penyelenggaraan Pemerintahan Daerah Secara Nasional.

Menteri Dalam Negeri Republik Indonesia. (2016). Keputusan Menteri Dalam Negeri Nomor: 120 - 10421 Tahun 2016 Tentang Penetapan Peringkat Dan Status Kinerja Penyelenggaraan Pemerintah Daerah Secara Nasional Tahun 2015.

Peraturan Pemerintah No.6 Tahun 2008 Tentang Pedoman Evaluasi Penyelenggaraan Pemerintahan Daerah

Peraturan Pemerintah No.58 Tahun 2005 Tentang Pengelolaan Keuangan Daerah

Petrie, M. (2002). A Framework for Public Sector Performance Contracting . OECD Journal on Budgeting, 117-153.

Republik Indonesia. (1945). Undang-Undang Dasar Republik Indonesia Tahun 1945.

Republik Indonesia. (2004). Undang-Undang Republik Indonesia Nomor 15 Tahun 2004 tentang Pemeriksaan Pengelolaan dan Tanggung Jawab Keuangan Negara.

Republik Indonesia. (2004). Undang-Undang Republik Indonesia Nomor 32 Tahun 2004 tentang Pemerintahan Daerah.

Republik Indonesia. (2006). Undang-Undang Republik Indonesia Nomor 15 Tahun 2006 Tentang Badan Pemeriksa Keuangan.

Sedyaningsih, P., \& Zaky, A. (2015). Pengaruh Karakteristik Pemerintah Daerah Dan Temuan Audit BPK Terhadap Kinerja Penyelenggaraan Pemerintahan Daerah (Studi pada Pemerintah Kabupaten di Sulawesi Selatan Tahun 2009 - 2012). Jurnal Ilmiah Mahasiswa FEB Universitas Brawijaya .

Sekaran, U. (2003). Research Methods For Business (4th ed.). New York: John Wiley \& Sons, Inc.

Sutopo, B., Wulandari, T. R., Adiati, A. K., \& Saputra, D. A. (2017). E-Government, Audit Opinion, and 
Performance. Australasian Accounting, Business and Finance Journal , 11 (4), 6-22.

Tarmizi, R., Khairudin, \& Jayadi, A. (2014). Analisis Kinerja Keuangan Pemerintah daerah kota Bandar Lampung Sebelum dan Setelah Memperoleh Opini WTP. Jurnal Akuntansi dan Keuangan , 5, 71-90.

Taufik, M., Darwanis, \& Arfan, M. (2014). Analisis Perbedaan Kinerja Keuangan Pemerintah Daerah Periode Opini WDP Dan Periode Opini WTP (Studi Pada Kabupaten/Kota Di Provinsi Aceh Tahun 2011-2012). Jurnal Akuntansi Pascasarjana Universitas Syiah Kuala , 3, 104-113.

Yasmin, A. (2016). Perbandingan Kinerja Pemerintah Kabupaten/Kota yang Memperoleh Opini WTP dan Non WTP. Bandar Lampung: Tesis Program Universitas Lampung. 